\title{
Perencanaan bantaran sungai bagian hilir Tukad Badung untuk rekreasi di Kota Denpasar
}

\author{
Ifham Azhar Abdurrahman ${ }^{1}$, Lury Sevita Yusiana ${ }^{2 *}$, Ni Wayan Febriana Utami²
}

1. Prodi Agroekoteknologi, Fakultas Pertanian, Universitas Udayana, Indonesia 80236

2. Prodi Arsitektur Pertamanan, Fakultas Pertanian, Universitas Udayana, Indonesia 80236

*E-mail: lury.yusiana@unud.ac.id

\begin{abstract}
Planning of the tukad Badung downstream riverside for the recreation in the City of Denpasar. River has a very big role for the development of human civilization, that is by providing a source of water for human life and become a common fertilizer located in the valley directly. The flows of Tukad Badung in Denpasar City has the function and potential as a source of irrigation, the source of raw water services, clean water service, drainage, and the future can be used as a recreational water. The purpose of this research is to plan for landscapes that are consistent with those location, and to recommend recreation activities as they can be presented in the landscape of the tukad Badung. The method used in this research is survey with observation, questionnaire, and literature review technique. The results of this research consists of general condition and research site location, inventory, analytical synthesis, conceptual, site planning, and planning of recreational activity. The final result was a site plan of riverside. The conclusion of this research was the physical condition divided by biophysical and social aspects. Concept plan has two stages, basic concepts and development concepts. The recommended activities and recreational facilities which planned were fishing, exercising, picnic, crossing bridges, and taking pictures. It can be suggest that in this research should be considered naturalness and cleanliness of area and create a characteristic at the site.
\end{abstract}

Keywords: planning, riverside, tukad Badung, recreation, site plan.

\section{Pendahuluan}

Sungai mempunyai peranan sangat besar bagi perkembangan peradaban manusia, yakni dengan menyediakan daerah subur yang umumnya terletak di lembah sungai dan sumber air sebagai sumber kehidupan yang utama bagi manusia. Kawasan tepi sungai yang bantarannya tertata asri menjadikan properti bernilai tinggi karena terjalin keharmonisan hidup antara manusia dan alam. Lingkungan yang teduh dengan tumbuhan di dekat air jernih yang mengalir menciptakan rasa nyaman. Kawasan bantaran sungai dapat dikembangkan menyatu dengan ruang terbuka hijau sebagai kawasan rekreasi dan olahraga bagi warga masyarakat.

Potensi dibidang lingkungan menjadikannya sebagai sabuk hijau kota di sepanjang bantaran sungai, yang bermanfaat bagi lingkungan dan masyarakat sekitar bantaran sungai. Potensi rekreasi dalam penelitan ini adalah pemanfaatan area bantaran sungai Tukad Badung sebagai tempat rekreasi baru bagi masyarakat sekitar dan umumnya masyarakat Denpasar.

Rumusan masalah dari penelitian ini yaitu mengetahui bagaimana perencanaan lanskap yang sesuai dengan kondisi tapak dan fasilitas aktivitas rekreasi apa yang dapat dihadirkan pada perencanaan bantaran sungai. Tujuan dari penelitian ini adalah membuat perencanaan lanskap yang sesuai dengan kondisi tapak, dan memberi rekomendasi fasilitas aktivitas rekreasi seperti apa yang dapat dihadirkan pada bantaran sungai bagian hilir Tukad Badung.

2. Metode

2.1 Tempat dan Waktu Penelitian

Penelitian dilaksanakan di bantaran sungai bagian hilir Tukad Badung Kota Denpasar, dengan panjang wilayah $\pm 150 \mathrm{~m}$ dan lebar wilayah $\pm 45 \mathrm{~m}$ (Gambar 1). Penelitian dilaksanakan dari bulan Agustus 2017 sampai dengan bulan November 2017. 


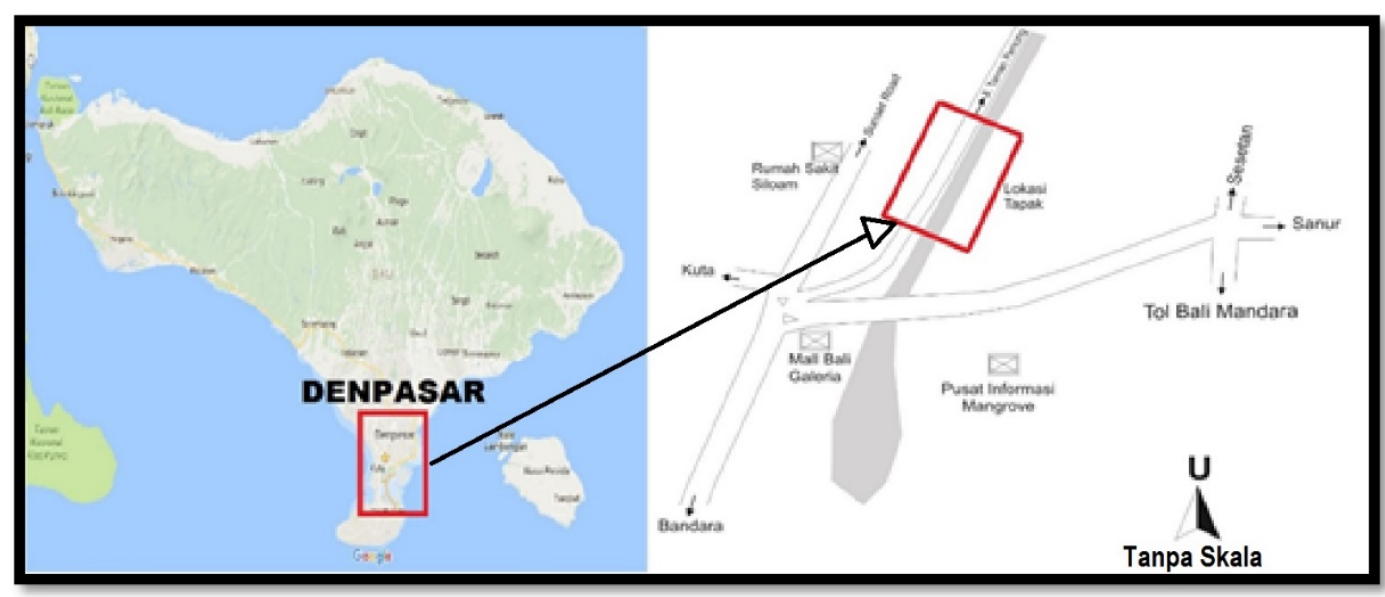

\subsection{Bahan dan Alat Penelitian}

Gambar 1. Peta dan Denah Lokasi Penelitian

Bahan yang digunakan dalam penelitian ini meliputi lembar kuesioner mengenai perencanaan bantaran sungai bagian hilir Tukad Badung untuk rekreasi di Kota Denpasar, sedangkan alat yang digunakan dalam penelitian ini meliputi peta dasar kawasan, kamera digital, alat tulis, meteran, dan perangkat komputer dengan piranti lunak seperti Corel Draw X4 Graphic, Arc GIS 10.4, Windows Paint, dan Google Earth.

\subsection{Metode Penelitian}

Metode yang dilakukan dalam penelitian ini adalah dengan menggunakan metode survei dengan teknik observasi, kuesioner, dan studi kepustakaan. Suharto (1994) mengemukakan bahwa metode dalam perancangan tata ruang lanskap tersebut meliputi inventarisasi data, analisis, sintesis, konsep dasar, konsep pengembangan, dan dibatasi sampai tahap perencanaan. Piranti lunak digunakan untuk menampilkan hasil perencanaan berupa Site Plan perencanaan bantaran sungai bagian hilir Tukad Badung untuk rekreasi di Kota Denpasar.

\section{Hasil dan Pembahasan}

\subsection{Kondisi Umum dan Lokasi Tapak Penelitian}

Tukad Badung bagian hilir berada dalam kawasan Desa Pemogan, Kecamatan Denpasar Selatan. Tukad Badung memiliki panjang aliran $\pm 21 \mathrm{~km}$, lebar sungai $\pm 24 \mathrm{~m}$, lebar bantaran sungai ditambah jogging track adalah $\pm 11 \mathrm{~m}$, berhulu di Desa Lukluk Kecamatan Mengwi Kabupaten Badung dan bermuara di daerah Teluk Benoa (Estuary Dam). Aksesibilitas menuju Tukad Badung bagian Hilir sangat mudah karena berdekatan dengan bypass I Gusti Ngurah Rai dan dekat dengan Mall Bali Galeria.

Batas perencanaan lokasi tapak adalah lahan yang berada di bagian hilir Tukad Badung yaitu sepanjang bantaran sungainya, dengan panjang wilayah $\pm 150 \mathrm{~m}$, lebar sungai $\pm 24 \mathrm{~m}$, lebar jogging track 2,8 $\mathrm{m}$, panjang jogging track $\pm 120 \mathrm{~m}$, lebar bantaran sungai tanpa jogging track $8 \mathrm{~m}$. Batas utara adalah $\pm 150 \mathrm{~m}$ ke utara dari area parkir yang sudah disediakan, batas timur adalah Jl.Tukad Baru Timur (seberang Jl.Taman Pancing), batas barat adalah Jl.Taman Pancing, batas selatan adalah ujung selatan Jl.Taman Pancing.

\subsection{Inventarisasi}

\subsubsection{Aspek Biofisik}

\subsubsection{Aksesibilitas}

Bantaran Tukad Badung di Jl.Taman Pancing yang menjadi lokasi penelitian memiliki jarak aksesibilitas dari tempat-tempat penting di Pulau Bali sebagai berikut (Tabel 1):

Tabel 1. Jarak Jl.Taman Pancing dengan Objek Penting di Pulau Bali

\begin{tabular}{clc}
\hline No. & \multicolumn{1}{c}{ Lokasi Objek } & Jarak \\
\hline 1. & Jarak ke Ibukota Kecamatan & $3,0 \mathrm{~km}$ \\
2. & Jarak ke Ibukota Provinsi & $7,6 \mathrm{~km}$ \\
3. & Jarak ke Central Parking Kuta & $3,9 \mathrm{~km}$ \\
4. & Jarak ke Bandara Ngurah Rai & $8,3 \mathrm{~km}$ \\
5. & Jarak ke Terminal Ubung & $11 \mathrm{~km}$ \\
\hline
\end{tabular}

Sumber : Monografi Desa Pemogan, 2017 


\subsubsection{Tanah}

Kondisi tanah di sekitar lokasi tapak dicirikan relief datar dan dataran fluvial. Ketinggian tempat di daerah ini berada antara 0 - 25 meter diatas permukaan laut. Berdasarkan aspek geologi dan tata lingkungan, kawasan ini cukup aman dari bahaya erosi karena wilayahnya relatif datar. Tanah pada kawasan dekat dengan waduk muara merupakan tanah berlumpur yang berasal dari pantai dan endapan yang dibawa oleh aliran sungai.

\subsubsection{Iklim Mikro}

Data iklim dalam perencanaan meliputi data curah hujan, suhu, kelembaban udara, radiasi penyinaran matahari, dan kecepatan angin. Daerah Kota Denpasar, selama tahun 2017 curah hujan terjadi di bawah normal (2-10,4 mm/bulan) terjadi di bulan Agustus - September. Pada bulan Desember curah hujan cukup tinggi $(622,8 \mathrm{~mm} / \mathrm{bulan})$. Suhu rata-rata berkisar antara $26,3^{\circ} \mathrm{C}-27,7^{\circ} \mathrm{C}$, kelembaban udara $78-84 \%$, radiasi penyinaran matahari sebesar 48 - 94\%, dan kecepatan angin 4- 8 knot. (Badan Pusat Statistik Provinsi Bali 2018).

\subsubsection{Vegetasi}

Jenis vegetasi dibedakan menjadi dua jenis, yaitu tanaman peneduh dan tanaman border. Tanaman peneduh adalah tanaman yang memiliki ciri berdaun lebar dan cenderung berakar tunggang dan juga nyaman digunakan untuk berteduh. Contoh tanaman peneduh yang ada di bantaran Tukad Badung adalah pohon kamboja (Plumeria sp), pohon tanjung (Mimusops elengi), pohon ketapang (Terminalia catappa), pohon beringin (Ficus benjamina), dan pohon trembesi (Albizia saman). Tanaman border adalah tanaman yang berfungsi sebagai pembatas antara lokasi tapak dengan jalan raya disamping tapak, tanaman border juga dapat digunakan sebagai penanda batas antara zona publik dan zona pribadi. Contoh tanaman border yang ada di bantaran Tukad Badung adalah pohon palem kuning (Chrysalidocarpus lutescens), rumput gajah (Pennisetum purpureum), pucuk merah (Syzygium oleana), bunga sepatu (Hibiscus rosa-sinensis), dan bunga asoka (Saraca asoca).

\subsubsection{Hidrologi}

Hasil pengukuran oleh proyek Hidrologi dan Hidrometri Bali, diperoleh debit rata-rata maksimum terjadi pada bulan Februari sebesar 3,48 m3/dt. Dan debit minimum terjadi pada bulan Agustus sebesar 2,06 $\mathrm{m}^{3} / \mathrm{dt}$. Pada musim kemarau (April - September) debit rata- rata yang tercatat di pos duga Ubung sebesar 2,39 $\mathrm{m}^{3} / \mathrm{dt}$, dan pada musim penghujan debit rata-rata mencapai $3,04 \mathrm{~m}^{3} / \mathrm{dt}$.

Aliran Tukad Badung terutama telah dimanfaatkan untuk mengairi lahan pertanian basah (sawah). Berikut ini disajikan nama bendungan dan luas daerah layanan irigasinya (Tabel 2).

Tabel 2. Layanan Irigasi Tukad Badung

\begin{tabular}{|c|c|c|c|}
\hline No & Nama Bendungan & & Luas Daerah Layanan Irigasi \\
\hline 1. & Bendung Mertagangga & & $134.00 \mathrm{Ha}$. \\
\hline 2. & Pengambilan Batan Nyuh & & $387.50 \mathrm{Ha}$. \\
\hline 3. & Pengambilan Mergaya & & $349.00 \mathrm{Ha}$. \\
\hline 4. & Bendung Gerak Tukad Badung & & $372.50 \mathrm{Ha}$. \\
\hline & & Jumlah $=$ & $1.243 .00 \mathrm{Ha}$. \\
\hline
\end{tabular}

Sumber: Proyek Hidrologi dan Hidrometri Bali, 2014

\subsubsection{Pemandangan}

Keadaan sebagian tapak kawasan bantaran sungai bagian hilir Tukad Badung dari segi pemandangan sudah memiliki kualitas pemandangan yang cukup mendukung (good view) dikarenakan lanskap pada kawasan ini sudah cukup tertata walaupun belum maksimal. Gambaran lokasi tapak bantaran sungai bagian hilir Tukad Badung dapat dilihat pada Gambar 2. 


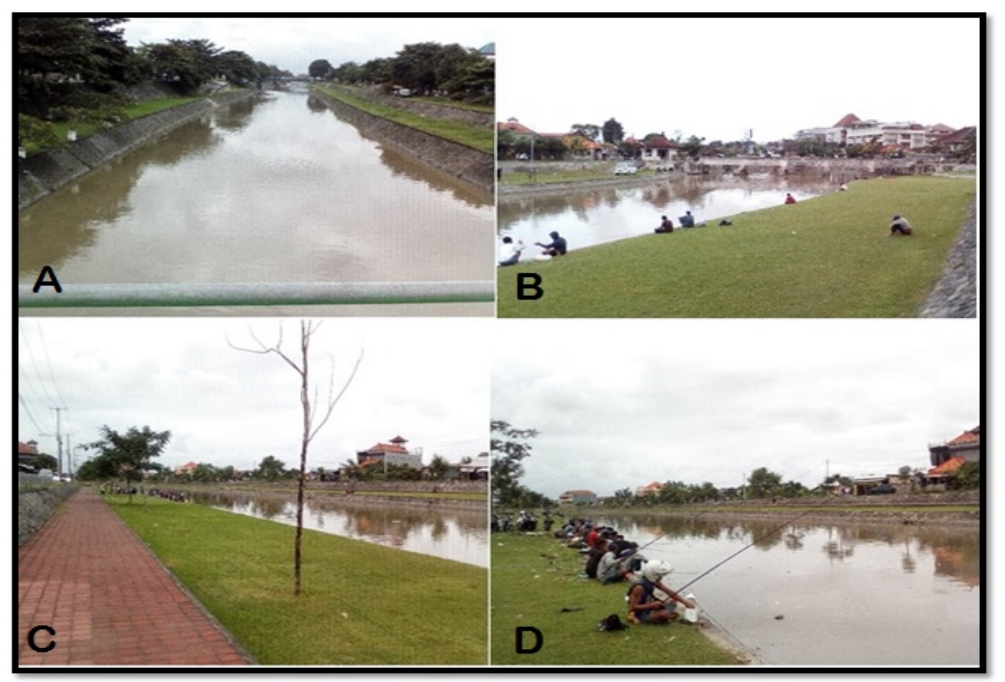
Keterangan:
A. Pemandangan Tukad Badung dari atas jembatan Taman Pancing.
B. Areal rumput untuk bersantai.
C. Jogging Track di Bantaran Tukad Badung.
D. Kegiatan pengunjung sedang memancing.

\subsubsection{Sedimentasi}

Perubahan tata guna lahan memicu terjadinya sedimentasi / pendangkalan pada luas penampang sungai dan juga memperbesar kapasitas debit yang masuk ke badan sungai sehingga akan memperbesar resiko terjadinya bencana banjir. Di sekitar alur sungai merupakan daerah permukiman yang sangat padat dengan kondisi ini badan sungai menjadi tempat pembuangan sampah, limbah rumah tangga dan limbah industri. Kondisi ini juga menyebabkan pendangkalan di beberapa ruas akibat sedimentasi sehingga kapasitas alur untuk mengalirkan debit banjir berkurang.

\subsubsection{Banjir Berkala}

Gelombang tinggi yang disebabkan oleh air pasang akan mengakibatkan banjir rob. Fenomena banjir rob terus terjadi dari tahun ke tahun terlepas ada reklamasi atau tidak. Pulau Bali akan tetap mengalami siklus banjir rob pada bulan Juni, Juli, Agustus, dan September. Akan tetapi tidak berpengaruh langsung pada daerah Estuary Reservoir dan daerah Taman Pancing karena adanya Bendung Gerak Tukad Badung yang menjadi pengendali banjir Kota Denpasar, dan Estuary Reservoir ini dilengkapi dengan bendung karet sebagai spillway (katup) dan pintu radial (Mangku, 2015)

\subsubsection{Aspek Sosial}

Sumber masalah kualitas lingkungan adalah masalah kepadatan penduduk. Konsekuensi logis dari besarnya jumlah penduduk adalah banyaknya lahan yang dimanfaatkan untuk permukiman mengakibatkan infiltrasi air hujan mengecil, limpasan permukaan bertambah besar. Sebagai akibat adalah meningkatnya sedimentasi yang mengurangi luas penampang basah sungai dan bahkan dapat menyumbat saluran drainase sehingga tidak berfungsi dengan baik.

\subsubsection{Keadaan Sosial Tapak}

Kepadatan penduduk Kecamatan Denpasar Selatan yaitu 5.330 jiwa/ $/ \mathrm{km}^{2}$ (Badan Pusat Statistik Kota Denpasar, 2014). Keadaan lingkungan social culture di sepanjang daerah aliran Tukad Badung ini di bagi atas beberapa kategori, yaitu karakteristik penduduk sepanjang DAS Tukad Badung umumnya pendatang yang terdiri dari etnis Tionghoa, etnis Arab, dan warga Bali asli yang umumnya pendatang urbanisasi. Jalur pejalan kaki pada kawasan ini dibagi menjadi dua tipelogi yaitu pedestrian penuh yang terletak disepanjang jalan utama yang berupa trotoar, dan semi pedestrian yang juga merupakan jalan pejalan kaki dan jalur bagi kendaraan bermotor, terdapat pada jalan-jalan lingkungan.

\subsubsection{Aktivitas dan Intensitas}

Berdasarkan hasil kuesioner yang sudah dilakukan di lokasi tapak. Rata-rata pengunjung yang datang ke lokasi ini adalah laki-laki remaja hingga dewasa. Kegiatannya adalah memancing dan bersantai di sekitar sungai. Lama kunjungan dilokasi ini bisa dua sampai empat jam sehari, mereka yang berkunjung ke lokasi ini biasanya datang seminggu sekali atau tiga kali dalam satu bulan. Kegiatan yang dapat dilakukan 
dilokasi ini antara lain memancing, bersantai, piknik keluarga, bermain, menikmati pemandangan, dan olahraga di jogging track yang berada di sebelah barat bantaran sungai.

\subsection{Analisis Sintesis}

Suhu dan kelembaban merupakan faktor utama penentu kenyamanan dan aktivitas manusia (Nurisjah dan Pramukanto, 2007). Menurut Laurie (1986) iklim yang ideal bagi kenyamanan manusia adalah udara yang bersih dengan suhu udara antara $27-28^{\circ} \mathrm{C}$, dan kelembaban antara $40-75 \%$, udara yang tidak terperangkap dan tidak berupa angin kencang. Suhu rata-rata yang dimiliki kawasan Tukad Badung yaitu 26$29^{\circ} \mathrm{C}$, yang masih berada dalam standar kenyamanan manusia di daerah tropis. Kelembaban yang cukup tinggi yaitu $74-83 \%$ relatif nyaman untuk melakukan suatu kegiatan dan aktivitas rekreasi.

Berbagai solusi dan pemecahan masalah pada saat tahap inventarisasi dapat dilihat pada Tabel 3 analisis dan sintesis.

Tabel 3. Analisis dan Sintesis

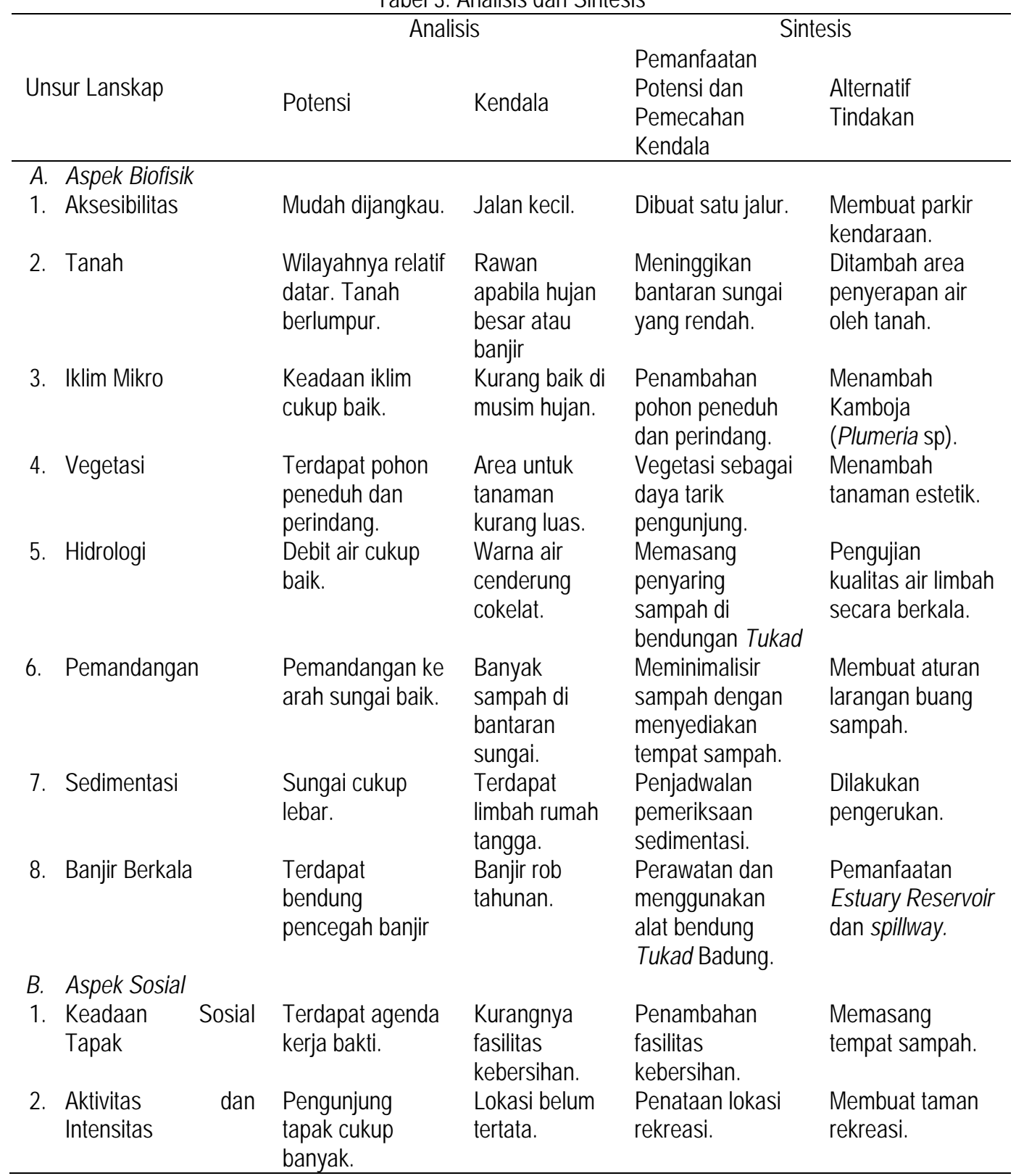




\subsection{Konsep}

3.4.1 Konsep Dasar

Konsep dasar penelitian ini adalah merencanakan sebuah kawasan rekreasi bantaran sungai yang memberikan manfaat bagi masyarakat sekitar dan juga pengunjung dalam memberikan alternatif hiburan dengan memanfaatkan sungai dan bantarannya berguna untuk aktivitas memancing, bersantai, maupun olahraga.

3.4.2 Konsep Pengembangan

Konsep pengembangan merupakan penjabaran dari konsep dasar yang dibagi menjadi beberapa konsep, yaitu konsep zonasi, sirkulasi, dan vegetasi.

3.4.2.1 Zonasi

Konsep zonasi bertujuan untuk menata dan mengalokasikan fungsi yang akan dikembangkan dalam tapak (Gambar 3). Terdapat tiga zona yang akan dibentuk yaitu zona penerimaan, zona aktivitas, dan zona penyangga.

a. Zona Penerimaan

Zona penerimaan ini berfungsi sebagai pintu masuk utama untuk memasuki kawasan bantaran sungai bagian hilir Tukad Badung. Zona penerimaan dibuat karakter ruang yang bersifat estetik dan informatif mengenai kegiatan rekreasi di dalam kawasan tapak.

b. Zona Aktivitas

Zona aktivitas berfungsi sebagai kawasan rekreasi. Zona aktivitas ini terdiri dari beberapa bagian yaitu area memancing, area piknik, area olahraga (jogging track), jembatan penyeberangan, dan area spot untuk berfoto.

c. Zona Penyangga

Zona penyangga merupakan zona yang mengelilingi kawasan rekreasi. Zona penyangga berfungsi sebagai buffer yang membatasi tapak dengan area di luar kawasan.

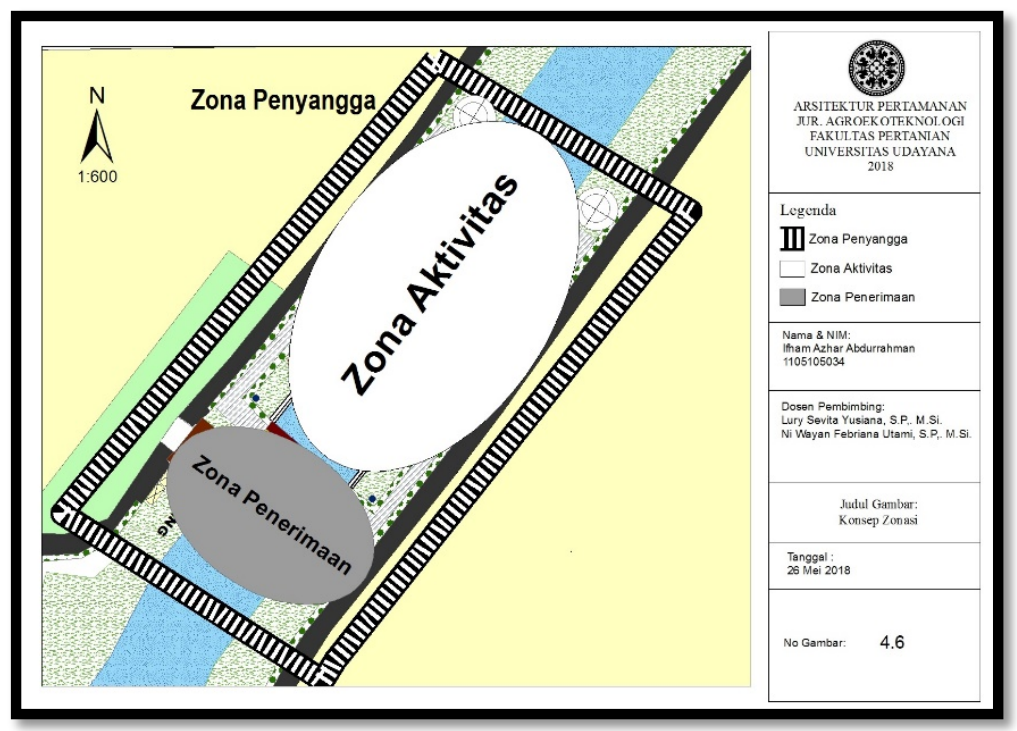

Gambar 3. Konsep Zonasi.

\subsubsection{Sirkulasi}

Skema sirkulasi dibuat rotasi, sehingga semua objek pada tapak akan dapat dilalui. Sirkulasi yang direncanakan berupa sirkulasi primer dan sirkulasi sekunder. Sirkulasi primer menghubungkan area penerimaan dengan area aktivitas rekreasi. Sirkulasi sekunder merupakan sirkulasi yang menghubungkan satu objek ke objek lainnya dalam area aktivitas rekreasi. Gambar 4 menunjukan skema sirkulasi. 


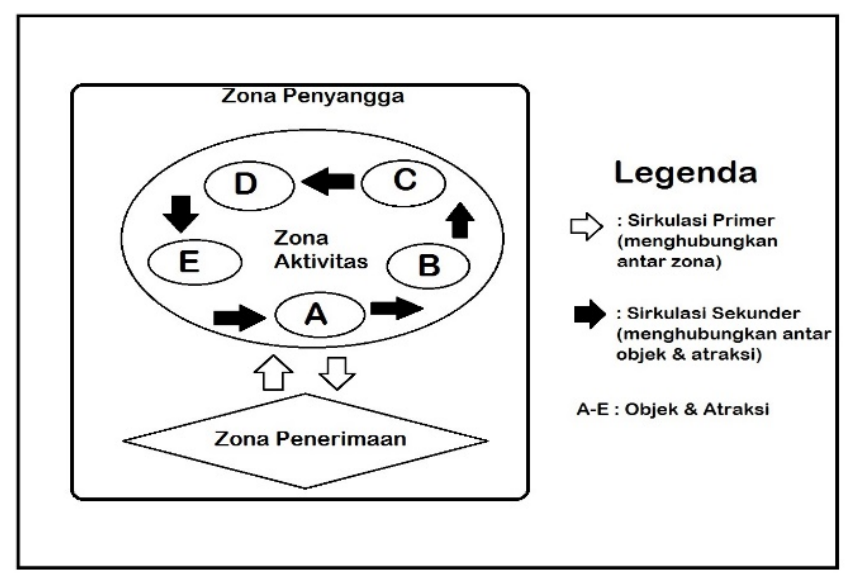

Gambar 4. Skema Sirkulasi.

\subsubsection{Vegetasi}

Konsep vegetasi yang akan direncanakan adalah konsep vegetasi alami sesuai dengan karakteristik dan keadaan tapak disana. Penambahan vegetasi adalah dengan menambahkan tanaman peneduh di sepanjang bantaran sungai, menambahkan tanaman yang berfungsi mencegah erosi bantaran sungai. Rumput yang ditata rapi di sepanjang bantaran sungai menambah daya tarik pengunjung juga masyarakat yang melintas di kawasan tersebut. Antara jalan kontrol sungai dan bantaran sungai ditanami tanaman pembatas (border) jalan agar diketahui mana area yang dapat dilalui kendaraan bermotor dan area bantaran sungai. Konsep vegetasi dapat dilihat pada Gambar 5.

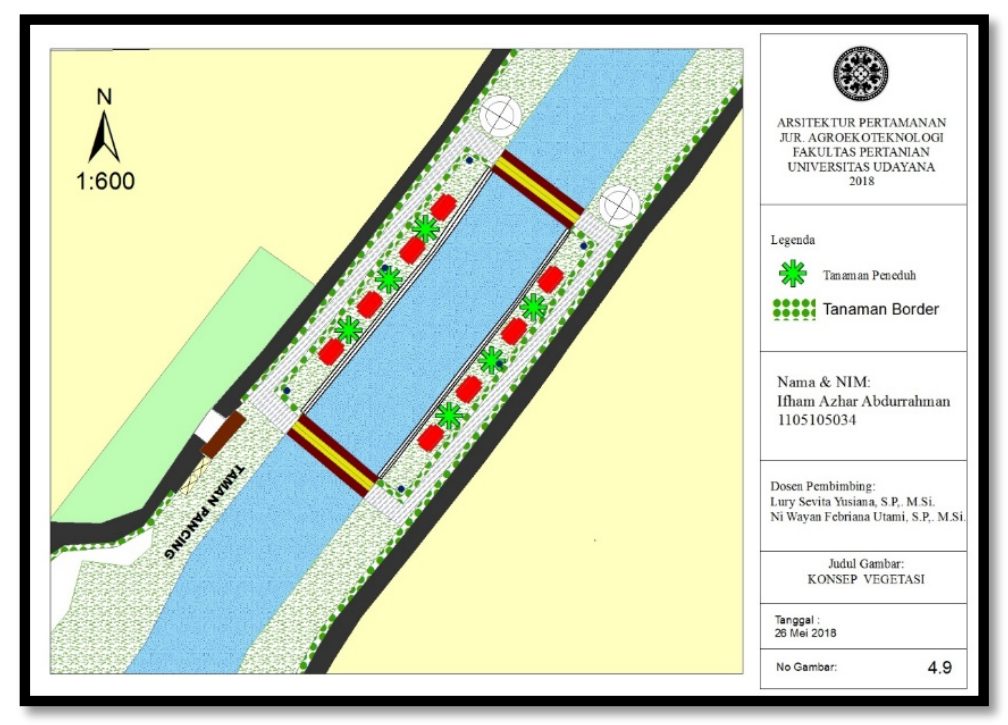

Gambar 5. Konsep Vegetasi.

\subsection{Perencanaan Tapak}

Tahap perencanaan merupakan suatu tahap pengembangan dari konsep-konsep yang menghasilkan suatu rencana tapak (Gambar 6). Tahap perencanaan ini meliputi perencanaan zona penerimaan, zona aktivitas, dan zona penyangga. Pembagian zona berfungsi untuk mengatur fungsi ruang serta memberikan alur bagi pengunjung dalam menikmati rekreasi sungai. 

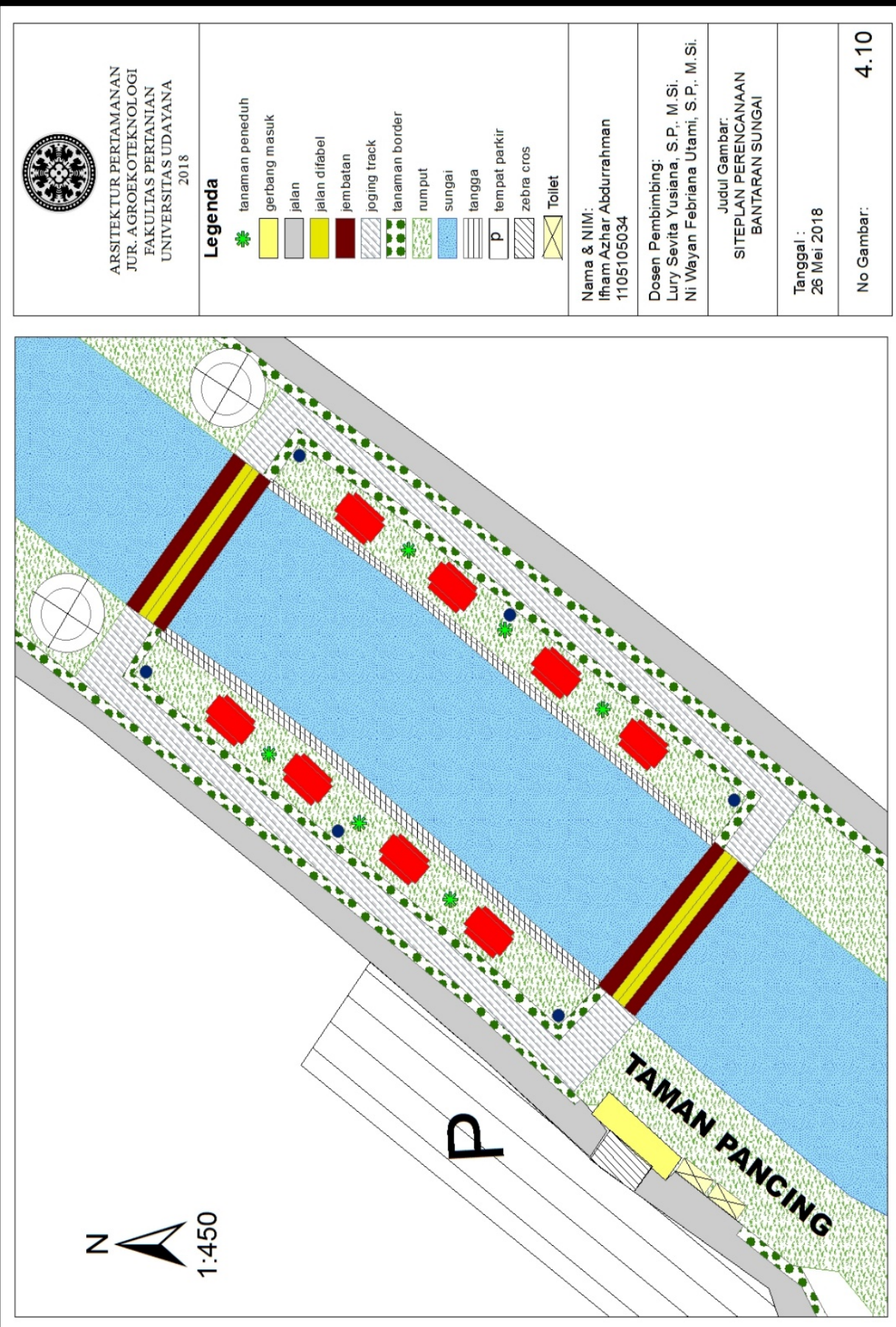

Gambar 6. Site plan Perencanaan Bantaran Sungai

\subsection{Tata Fasilitas Rekreasi}

Tata fasilitas rekreasi pada tapak berada di zona aktivitas. Jenis fasilitas rekreasi yang direncanakan antara lain: 1) Memancing ikan. 2) Olahraga. 3) Piknik. 4) Menyeberangi jembatan. 5) Berfoto. 


\section{Simpulan dan Saran \\ 4.1 Simpulan}

Kondisi fisik dan sosial bantaran Tukad Badung berdasarkan analisis dan sintesis dibagi dua yaitu aspek biofisik (aksesibilitas, tanah, iklim mikro, vegetasi, hidrologi, pemandangan, sedimentasi, banjir berkala) dan aspek sosial (keadaan sosial tapak dan aktivitas intensitas). Berdasarkan aspek biofisiknya potensi tapak ini sudah dapat digunakan sebagai area rekreasi. Sedangkan untuk aspek sosial potensinya adalah hubungan sosial yang erat yang diwujudkan dengan kerja bakti bersama, intensitas pengunjung yang selalu ramai di sore hari, kekurangannya adalah lokasi yang belum tertata rapi. Konsep perencanaan lanskap yang dihasilkan meliputi dua tahap, yaitu merencanakan konsep dasar dan berikutnya adalah merencanakan konsep pengembangan yaitu zonasi, sirkulasi, dan vegetasi. Rekomendasi fasilitas aktivitas rekreasi yang direncanakan meliputi kegiatan memancing ikan, berolahraga (jogging), piknik, menyeberangi jembatan, dan berfoto.

\subsection{Saran}

Hasil penelitian perencanaan bantaran Tukad Badung ini dapat dilanjutkan pada tahap perancangan yang lebih detail pada objek rekreasi yang telah direncanakan. Hasil penelitian ini juga dapat digunakan sebagai bahan pertimbangan bagi pengelola bantaran sungai dan juga pemerintah dalam mengembangkan potensi kawasan bantaran Tukad Badung. Tahap perancangan sebaiknya mempertimbangkan kealamian dan kebersihan kawasan dan meciptakan ciri khas pada tapak.

\section{Daftar Pustaka}

Badan Pusat Statistik Kota Denpasar. (2014). Denpasar Dalam Angka 2014. Available online at: www.denpasarkota.bps.go.id (diakses 02 Desember 2017).

Badan Pusat Statistik Provinsi Bali. (2018). Bali Dalam Angka 2018. Available online at: www.bali.bps.go.id (diakses 09 Mei 2018).

Laurie. (1986). Pengantar kepada Arsitektur Pertamanan. Intermatra, Bandung.

Mangku. (2015). Reklamasi Teluk Benoa diharapkan Kembalikan Pulau yang ada. TangkasNews. Available online at : www.tangkasnews.com (diakses 25 November 2017).

Monografi Desa Pemogan (2017). Jarak jalan Taman Pancing dengan Objek Penting di Bali. Desa Pemogan. Available online at: www.pemogan.denpasarkota.go.id (diakses 09 Mei 2018).

Nurisjah,S. dan Q. Pramukanto. (2007). Penuntun Praktikum Perencanaan Lanskap. Institut Pertanian Bogor, Fakultas Pertanian, Jurusan Budidaya Pertanian, Program Studi Arsitektur Lanskap, Bogor.

Proyek Hidrologi dan Hidrometri Bali (2014). Studi Lingkungan Hidup Tukad Badung Bali. Available online at: www.academia.edu (diakses 04 Maret 2018).

Suharto. (1994). Dasar-Dasar Pertamanan, Menciptakan Keindahan dan Kerindangan. Media Wiyata, Semarang. 